\title{
The EU's Romance with Specialized Adjudication
}

\author{
Rochelle Dreyfuss
}

Published online: 28 November 2016

(C) Max Planck Institute for Innovation and Competition, Munich 2016

Within the EU, specialized adjudication is having a "moment." Now that over ninety countries have established specialized tribunals to hear intellectual property (IP) cases, members of the EU are about to create a Unified Patent Court (UPC). ${ }^{1}$ At the same time, the European Commission is recommending a standing Investment Court to deal with investor-state dispute resolution (ISDS) under the TTIP, the Transatlantic Trade and Investment Partnership Agreement. ${ }^{2}$

The EU's enthusiasm for these courts is easy to understand. The wave of specialized IP courts follows the success of the US Court of Appeals for the Federal Circuit. Prior to that court's establishment, patent appeals were heard by regional circuit courts and, for determinations within the patent office, by the Court of Customs and Patent Appeals. Because US appellate courts are not bound by one another's legal determinations, the law across the nation had been heavily balkanized. The Federal Circuit created a uniform and more predictable patent jurisprudence. As a bonus, the judges developed technical proficiency and deep familiarity with a highly complex statutory regime. Litigating cases is now more efficient and opportunistic litigation behavior has diminished. The members of the Unitary Patent System are hoping for similar results when the Unitary Patent, which will create rights in all their nations, comes into being.

At the international level, the Investment Court is modeled on the WTO's Appellate Body. Here, the problem was that disputes under the GATT were resolved

\footnotetext{
1 Agreement on a Unified Patent Court, 2013 O.J. (C 175) 1; Regulation 1257/2012, of the European Parliament and of the Council of 17 December 2012 on Implementing Enhanced Cooperation in the Area of the Creation of Unitary Patent Protection, 2012 O.J. (L 361) 1.

2 Transatlantic Trade and Investment Partnership, Ch. II, Arts. 9 and 10, https://perma.cc/NG4H-N86U (accessed 15 August 2016).
}

R. Dreyfuss ( $($ )

Pauline Newman Professor of Law

NYU School of Law, New York, USA

e-mail: rochelle.dreyfuss@nyu.edu 
through ad hoc tribunals and diplomacy; every case was essentially argued from first principles. The Appellate Body, a standing court that now reviews the decisions of these ad hoc tribunals, developed normative principles and a jurisprudence constante; it enhanced the legitimacy of WTO dispute resolution; and, as with the Federal Circuit, improved the efficiency of adjudication. In the ISDS context, the legitimizing effect of a permanent court would be even more dramatic. Currently, ad hoc panels are composed of arbitrators who are paid on a dispute-by-dispute basis and who also regularly serve as party representatives in other ISDS cases. A dedicated judiciary would eliminate the perception that the adjudicators' private interests in generating disputes and adopting rules beneficial to their (usually wellheeled) clients will influence their decisions.

As the EU considers the UPC and an Investment Court, it should, however, recognize that experience with the Federal Circuit has revealed deficiencies and disappointments. Centralization has not eliminated bad litigation behavior. Rather, it has shifted it to the lower courts and back to the patent office. Within the Federal Circuit, advocates "drill down." They argue about the import of minor linguistic inconsistencies and exploit even the smallest lacunae in the law. Judges do not resist the impulse to allow cases to proliferate, for even adjudicators who are paid regular salaries have a strong interest in enhancing the importance of the tribunal on which they sit and thus, their own prestige. Furthermore, uniformity (treating like cases alike) is not the same as accuracy (reaching the just result in each case and correctly implementing legislative intent). Isolation from the jurisprudential mainstream and capture by repeat players has led to patent-friendly law, more patents, and a burgeoning caseload. To achieve predictability, the court has tended to favor bright line rules, but as the rules versus standards debate demonstrates, bright line rules do not always do justice between the specific parties standing before the court. It is not insignificant that the Supreme Court, whose main role is to resolve conflicts among the circuits, has nonetheless chosen to review a considerable number of Federal Circuit decisions and has reversed a disproportionate number of them. The Court has repeatedly objected to the "rigidity" of the Federal Circuit's jurisprudence and to its tendency to favor patentees. ${ }^{3}$

Proponents of specialization appear to have convinced members of the Unitary Patent System that a better approach would be to establish two layers of specialization and to eliminate generalist input by largely cutting out the capacity of the Court of Justice to review the Court of Appeal. That approach would reduce opportunism and avoid dysfunctional relationships among trial, appellate, and apex courts. However, it is likely to undermine the system's legitimacy, especially in the early years of the UPC's existence, when patent holders alone will choose the type of patent to acquire and thus where disputes will be litigated. To preserve its viability, the UPC will be disposed to decide cases in ways that will induce inventors to seek Unitary Patents: that is, to strengthen patent protection at the expense of the public interest in access and in other important social policies. To

\footnotetext{
3 KSR Int'l Co. v. Teleflex Inc., 550 U.S. 398 (2007) is a prime example. The Supreme Court raised the height of the inventive step and began its decision "by rejecting the rigid approach of the Court of Appeals," at 415.
} 
make matters worse, the UPC differs from the Federal Circuit in that it will hear no other types of cases and from no one other than members of the heavily specialized patent bar. Thus, its insulation from mainstream jurisprudence will be absolute.

Now that Brexit has created an opportunity to revise the Unitary Patent System, it is worth reconsidering the decision to double down on specialization and to dispense with input from the tribunals that regularly deal with such countervailing considerations as competition, health, labor, and cultural policy. In the US, various proposals have been made to reduce the isolation of the Federal Circuit and to broaden the epistemic community from which it hears ${ }^{4}$; some of these suggestions could be adapted for Europe.

An Investment Court may be similarly prone to resolve disputes in ways that aggrandize its role, which is to say, to reach decisions that will induce investors to assert more claims. The comfort its proponents draw from the success of the Appellate Body [and to a lesser extent, from the European Court of Human Rights (ECHR)] is largely misplaced. Only states have standing before the Appellate Body and states are not as likely as private investors to assert claims that challenge sovereign authority to regulate in the public interest. As the Supreme Court reasoned in another context involving private (as opposed to public) claims, governmental discretion is an important check on the "potential for international friction." It is certainly possible that both a state and its investors will be interested in the same issue (Australia's legislation on tobacco packaging was the subject of both ISDS and WTO complaints). However, in many situations, their interests diverge. For example, the US would be unlikely to bring a WTO case that parallels Eli Lilly's ISDS complaint against Canada. Lilly asserts that post NAFTA, judges cannot reinterpret patent law, yet US judges regularly accommodate technological developments by refining patent doctrine.

There are other differences between ISDS and WTO challenges. Because WTO dispute resolution leads to remedial action and not monetary damage awards, the incentive to bring cases is much reduced. In that way, the ECHR is similar. While individual actions are available, relief is directed more to structural reform than to compensation. Moreover, the ECHR's well-developed principles of deference prevent its decisions from intruding too deeply into national policy space.

Proponents of an Investment Court should take these factors into account. For the court to succeed as well as the ECHR or the Appellate Body have, it is not enough to be specialized. Rather, success requires a healthy appreciation for sovereign authority and, for IP, considerable skepticism regarding the prerogatives of right holders. For an Investment Court, this may mean the adoption of additional positive law. For instance, the TTIP would go a long way toward reducing IP disputes and safeguarding national interests if it specified that registering a right is not in itself an investment - that is, if it defined investment to require organizing and operating an

\footnotetext{
${ }^{4}$ Eg. D.P. Wood, "Is it Time to Abolish the Federal Circuit's Exclusive Jurisdiction in Patent Cases?" 13 Chicago Kent Law Journal 1 (2013); C.A. Nard and J.F. Duffy, "Rethinking Patent Law's Uniformity Principle" 101 Northwestern University Law Review 1619 (2007).

5 RJR Nabisco v. European Community, 136 S.Ct. 2090, 2106 (2016).
} 
enterprise in the territory of the party and committing capital or other resources in the expectation of local gain. ${ }^{6}$

None of this is to say that the EU is wrong to adopt specialized courts. But it must not romanticize their potential.

\footnotetext{
${ }^{6}$ Eg. Model Text for the Indian Bilateral Investment Treaty, Art. 1.4, https://perma.cc/P8FW-T4VK (accessed 22 August 2016). 